\title{
Analisis Empiris Atas ORDPATH Encoding Untuk Kinerja Insert Node Pada Ordered XML Tree
}

\author{
Irvanizam Zamanhuri \\ Jurusan Informatika, Fakultas Matematika dan Ilmu Pengetahuan Alam, Universitas Syiah Kuala \\ J1. Syech Abdurrauf No. 5, Darussalam Banda Aceh 23111, Propinsi Aceh \\ Email: irvanizam.zamanhuri@informatika.unsyiah.ac.id
}

Masuk: 22 Januari 2015; Direvisi: 20 Februari 2015; Diterima: 23 Februari 2015

\begin{abstract}
The eXtensible Markup Language (XML) has quickly become the de facto standard for data exchange via web. An XML document can be viewed as an ordered tree that has at least one node. Each node must be labeled by using a scheme approach to describe the XML data structure. There are two famous existing encodings, namely Dewey and Inteval Encodings. In this paper, ORDPATH encoding based on Dewey together with the two other encodings are empirically demontrated on dblp, nasa, and treebank datasets. The results show that while a new node was inserted into the tree, Dewey and Interval have to relabel the inserted node's siblings and modify the interval number of the sibling nodes, respectively. Whereas, the ORDPATH eliminates this problem by adding an even number used as a caret for the new insertion node.
\end{abstract}

Keywords: Ordered Tree, XML, ORDPATH.

\begin{abstract}
Abstrak. EXtensible Markup Language (XML) terus menjadi standard untuk penukaran data melalui web. Sebuah dokumen XML dapat ditinjau menjadi tree terurut yang berisikan sedikitnya satu node. Setiap node harus dilabelkan menggunakan sebuah algoritma pelabelan untuk mendeskripsikan struktur data XML tersebut. Ada dua algoritma encoding yang terkenal selama ini, Dewey dan Interval encoding. Pada tulisan ini, metode ORDPATH yang berbasiskan Dewey bersama-sama dengan Dewey dan Interval didemontrasikan secara empiris dengan menggunakan dataset dblp, nasa, dan treebank. Hasil menunjukkan bahwa ketika node baru dimasukkan ke dalam tree, Dewey dan Interval harus melakukan pelabelan kembali dan memodifikasi interval sibling node. Akan tetapi, ORDPATH dapat mengatasi masalah ini dengan memberikan angka genap yang digunakan sebagai penanda untuk node baru.
\end{abstract}

Kata Kunci: Ordered Tree, XML, ORDPATH.

\section{Pendahuluan}

Dewasa ini XML sangat cepat popular dan menjadi standar untuk pertukaran informasi melalui internet (Tatarinov, dkk., 2002; Lu, dkk., 2005; O’Neil, dkk., 2004; Soltan, dkk., 2006). XML dapat menyajikan beragam informasi yang dihimpun melalui sebuah berkas dokumen. Salah satu website yang menyajikan informasi terkemuka dengan menggunakan dokumen XML sebagai tempat penyimpanan datanya adalah Database Very Large Project (DBLP). Website ini menghimpun lebih dari 1,9 juta artikel, jurnal, dan proseding Computer Science serta link website ilmuan komputer secara up-to-date.

Namun, penyimpanan data melalui dokumen XML menjadi hambatan ketika sebuah informasi baru harus ditambahkan ke dalam dokumen XML. Hal ini disebabkan karena besarnya ukuran file sehingga sulit mencari posisi yang tepat untuk menambahkan informasi baru tersebut. Selain itu, perubahan struktur dan alur informasi akan mengakibatkan perubahan yang besar pada struktur data XML.

Untuk mengatasi hambatan tersebut, banyak peneliti telah mengusulkan penggunaan sistem basis data yang terelasi dengan mentransformasikan struktur data XML ke dalam sebuah sistem basis data (Tatarinov, dkk., 2002; Deutsch, dkk., 1999; Florescu \& Kossmann, 1999; Shanmugasundaran, 2001; Shimura, dkk., 1999). Namun yang menjadi fokus pada pendekatan 
ini adalah mencari model schema untuk pelabelan XML terurut (Ordered XML documents) yang bagus, efisien, dan mampu mendeskripsikan struktur data XML seperti aslinya.

Sebuah dokumen XML dapat dipresentasikan menjadi tree yang terurut (Zamanhuri, 2014). Setiap tree mempunyai setidaknya sebuah node yang merupakan root dari tree atau terdiri dari beberapa node. Urutan node di dalam tree menunjukkan urutan data atau informasi yang berada pada dokumen original XML. Karena ini merupakan sebuah tree, maka konsep children, sibling, dan parent nodes dapat diterapkan pada dokumen XML.

Banyak peneliti telah mengusulkan metode-metode pelabelan node pada sebuah tree (Zamanhuri, 2014). Dua yang paling terkenal adalah Dewey (Tatarinov, dkk., 2002) dan Interval (Dagys, 2008) encoding. Metode Dewey mendefinisikan node dengan menampilkan urutan bilangan integer sehingga label setiap node menjadi seperti katalog buku di perpustakaan atau urutan daftar isi pada buku. Sedangkan interval encoding menglabelkan setiap node di dalam tree dengan mendefinisikan nilai interval yang ditentukan melalui penambahan (increment) nilai integer ketika setiap node dijelajah secara pre-order traversal.

Selain itu, terdapat juga beberapa metode pelabelan node baru yang berbasiskan Dewey telah ditemukan. Salah satunya adalah yang diusulkan melalui jurnal (O'Neil, dkk., 2004) yaitu ORDPATH encoding. Metode ini menginisialisasikan setiap label node dengan bilangan ganjil integer dan menggunakan bilangan genap sebagai tanda sisipan (caret) ketika sebuah node baru ditambahkan ke dalam tree. Ketiga metode encoding yang disebutkan di atas mempunyai cara dan teknik penambahan node baru yang berbeda-beda.

Dalam penulisan ini, penulis akan menunjukkan dan membandingkan proses penambahan node dengan menggunakan ketiga encoding tersebut dan menampilkan kelebihan ORDPATH encoding dari kedua encoding yang lain terutama pada kasus penambahan node baru. Selain itu, penulis juga akan membahas kembali ide dan gambaran algoritma pelabelan node menggunakan metode ORDPATH.

\section{Tinjauan Pustaka}

\subsection{Ordered XML Tree}

Sebuah dokumen XML yang berisikan elemen, attribut dan data dapat dilihat sebagai sebuah tree (Tatarinov, dkk., 2002). Tree mempunyai root dan node-node sebagai representasi dari elemen, atribut dan data dari dokumen original XML. Dokumen XML tersebut merupakan model data terurut sehingga posisi suatu elemen XML tidak dapat dipindahkan ke posisi lain. Perpindahan ini mengakibatkan perubahan urutan node di dalam XML tree. Kode 1 dan Gambar 1 memperlihatkan dokumen XML yang sangat sederhana dan hasil konversi XML ke dalam ordered XML tree.

Kode 1. Dokumen XML Sederhana

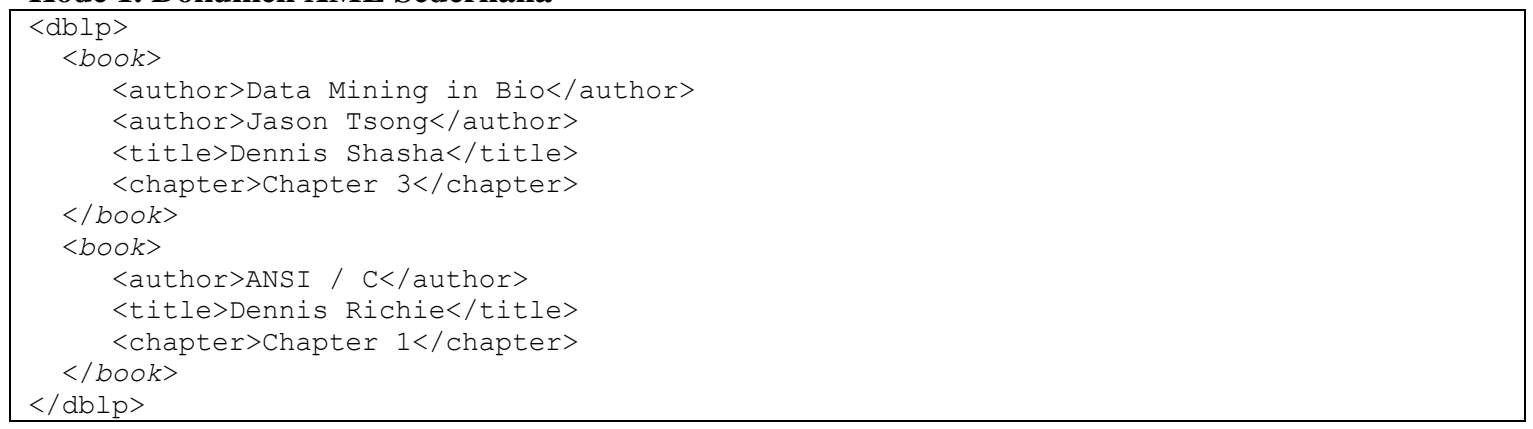

Sebuah tree dibangun oleh sedikitnya satu node atau beberapa node-node yang saling berhubungan atau dikenal dengan complete tree. Complete Tree Sebuah node memiliki setidaknya parent, sibling, dan children node. Dari Gambar 1, node dblp merupakan parent node dari node book. Node author, title, dan chapter adalah children node dari node book. Sedangkan node title merupakan sibling node dari node author. 


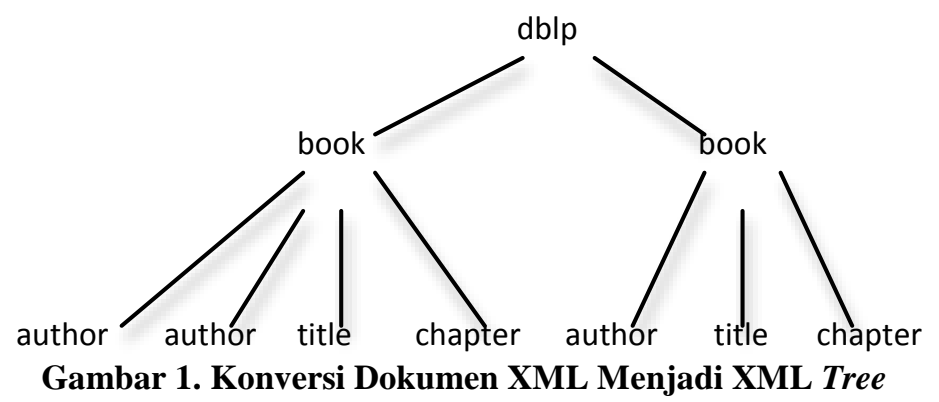

\subsection{Properti Tree}

Menurut Gros \& Yellen (2010), directed tree adalah sebuah graf yang mempunyai arah. Salah satu contoh graf ini adalah rooted tree yang mana setiap edge-nya secara implisit berarah dari akar treenya. Dalam rooted tree, depth atau level dari sebuah vertex $v$ adalah jarak vertex $v$ dengan root dan height dari rooted tree adalah jarak path yang terpanjang dari root. Selain itu, rooted tree juga mempunyai beberapa properti penting seperti parent, child, siblings, descedant, ancestor, leaf, dan internal vertex.

Definisi 1. Jika vertex $v$ secara langsung terhubung dengan vertex $w$ melalui sebuah path dari root ke $w$, maka $v$ adalah parent dari $w$, dan $w$ adalah child dari $v$.

Definisi 2. Vertex-vertex yang mempunyai parent yang sama dinamakan dengan siblings.

Definisi 3. Vertex $w$ dinamakan descendant dari vertex $v$ (dan $v$ disebut ancestor dari $w$ ), jika $v$ berada pada path yg unik dari root ke $w$. Jika $w \neq v$, maka $w$ adalah proper descendant dari $w$ (dan $v$ adalah proper ancestor dari $w$ ).

Definisi 4. Leaf adalah vertex yang tidak mempunyai children. Sedangkan internal vertex adalah vertex yang mempunyai paling sedikit satu child.

Gambar 2 memperlihatkan contoh-contoh dari ketujuh properti dari rooted tree. Gambar 2 dapat dijelaskan bahwa height dari tree tersebut adalah 3. Vertex r, a, b, c, dan d merupakan Interval Vertex. Vertex e, f, g, h, i, dan j adalah leaf dari tree. Vertex g, h, dan i adalah siblings. Kemudian, vertex a merupakan ancestor dari $\mathrm{j}$, dan $\mathrm{j}$ merupakan descendant dari a.

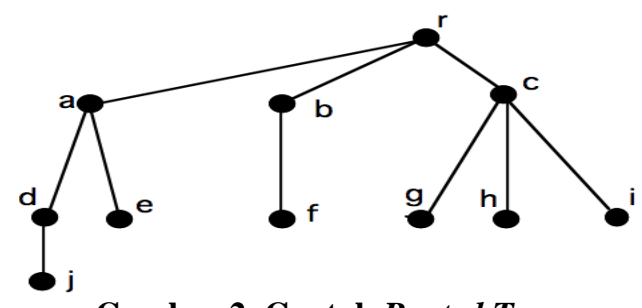

Gambar 2. Contoh Rooted Tree

\subsection{Konsep Dewey, Interval, dan ORDPATH Encoding}

Metode Dewey encoding pertama sekali diperkenalkan oleh Tatarinov merupakan metode pelabelan XML tree seperti pengkode katalog buku. Dalam metode ini, setiap node dilabelkan dengan menggunakan kombinasi antara label parent node-nya dengan sebuah bilangan positif integer. Jika $u$ merupakan anak ke- $x$ dari node $s$ pada XML tree, maka label untuk node $u$, label $(u)$ adalah penggabungan label dari node $s$ dan $\mathrm{x}$ yang dipisahkan oleh sebuah karakter '.', atau dipresentasikan dengan label $(u)=$ label $(s)$.x. Sebagai contoh, jika label node $u$ adalah 1.5.3, maka label untuk child node yang ke-5 dari node $u$ adalah 1.5.3.5.

Interval encoding merupakan metode encoding untuk melabelkan node dengan 
menggunakan nilai interval (range) dengan teknik penelusuran pre-order traversal (Augsten, 2009). Nilai interval dari sebuah children akan selalu berada di antara nilai interval parentnya.

Sedangkan ORDPATH encoding yang dipaparkan pada tulisan (O’Neil, dkk., 2004) merupakan metode encoding berbasiskan Dewey yang menggunakan bilangan ganjil. Namun, metode ini juga menggunakan bilangan genap sebagai tanda sisipan (caret) untuk menambahkan node baru ke dalam tree.

\subsection{Penyimpanan Elemen XML ke dalam Sistem Manajemen Basis Data}

Dokumen XML dapat disimpan dan dikelola ke dalam Database Manajement System (DBMS) menggunakan object relational DBMS (Ferraz, dkk., 2010). Menurut Tatarinov, dkk. (2002), dokumen tersebut dipecahkan menjadi dua relasi: Path (id, path) dan Edge (dewey, path_id, value). Pada relasi Edge, atribut Dewey menyimpan kode node yang dibentuk melalui algoritma Dewey. Sedangkan relasi Path menyimpan informasi tentang path dari elemen XML yang disimpan. Nama node tidak pernah disimpan di dalam relasi Edge karena nama node dapat diperoleh melalui atribut path pada relasi Path. Contohnya, hirarki dokumen XML dari Gambar 3 yang telah dibentuk kode node menggunakan algoritma Dewey dapat disimpan ke dalam DBMS. Tabel 1 dan 2 adalah tabel relasi Path dan Edge dari Gambar 3. Sedangkan Tabel 3 adalah tabel relasi dokumen.

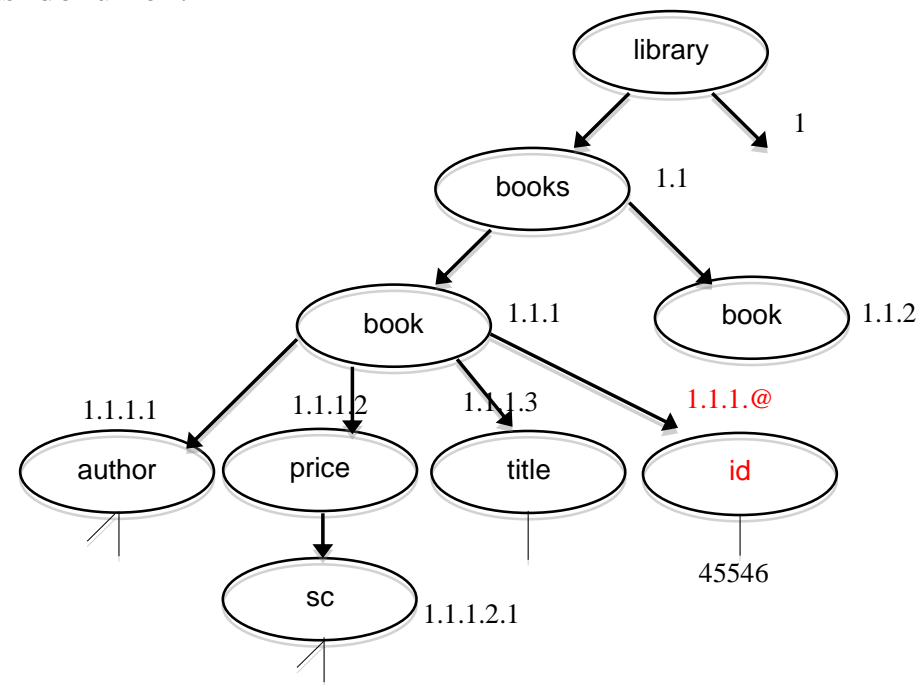

Gambar 3. Hirarki Dokumen XML dengan Algoritma Dewey

Ketika semua elemen dari dokumen XML sudah ada di dalam tabel relasi Path dan Edge, maka query-query seperti parent, children, ancestor, descendant, dan sibling dapat diperoleh dengan menggunakan ekspresi Structure Query Language (SQL).

Tabel 1. Tabel Relasi Path

\begin{tabular}{cl}
\hline id & \multicolumn{1}{c}{ Path } \\
\hline 1 & library \\
\hline 2 & library/books \\
\hline 3 & library/books/book \\
\hline 4 & library/books/book/@id \\
\hline
\end{tabular}

\begin{tabular}{cccc}
\multicolumn{4}{c}{ Tabel 2. Tabel Relasi Edge } \\
\hline value & path_id & dewey & doc_id \\
\hline 1 & 1 & 1 \\
\hline 2 & 1.1 & 1 \\
\hline 3 & 1.1 .1 & 1 \\
\hline 3 & 1.1 .2 & 1 \\
\hline 45546 & 4 & $1.1 .1 . @$ & 1 \\
\hline
\end{tabular}

Tabel 3. Tabel Relasi Dokumen

\begin{tabular}{cl}
\hline id & \multicolumn{1}{c}{ name } \\
\hline 1 & Library \\
\hline 2 & Cars \\
\hline 3 & Videos \\
\hline 4 & Universities \\
\hline
\end{tabular}

\section{Metodologi Penelitian}

\subsection{Bahan}

Bahan yang digunakan dalam penelitian ini adalah delapan jenis dataset dalam bentuk dokumen XML yang berupa file XML dblp, nasa, dan Treebank. Dataset dblp berisikan lebih dari 1.9 juta artikel, jurnal, dan proceeding Computer Science. Dataset nasa berisikan tentang data asronomik. Sedangkan dataset Treebank berisikan data linguistik dalam Bahasa Inggris. Karakteristik dari dataset tersebut dapat dilampirkan pada Tabel 4. 
Tabel 4. Dokumen XML (dataset)

\begin{tabular}{ccccc}
\hline Dataset & Ukuran $(\boldsymbol{M B})$ & Jumlah Node & Max/Avg depth & Max/Avg fanout \\
\hline Dblp-1 & 0.1 & $2 \mathrm{~K}$ & $2 / 1$ & $199 / 1999$ \\
\hline Dblp-2 & 1.5 & $30 \mathrm{~K}$ & $3 / 3$ & $974 / 56$ \\
\hline Dblp-3 & 4.1 & $79 \mathrm{~K}$ & $3 / 3$ & $8662 / 107$ \\
\hline Dblp-4 & 7.2 & $139 \mathrm{~K}$ & $3 / 3$ & $15 \mathrm{~K} / 107$ \\
\hline nasa & 23.8 & $533 \mathrm{~K}$ & $10 / 7$ & $2 \mathrm{~K} / 225$ \\
\hline Treebank & 85.4 & $2 \mathrm{M}$ & $36 / 8$ & $56 \mathrm{~K} / 1.6 \mathrm{~K}$ \\
\hline Dblp-5 & 260 & $5 \mathrm{M}$ & $3 / 3$ & $92 \mathrm{~K} / 2 \mathrm{~K}$ \\
\hline Dblp-6 & 592 & $11 \mathrm{M}$ & $3 / 3$ &
\end{tabular}

\subsection{Metode Penelitian}

Untuk membandingkan antara ketiga metode encoding, proses penambahan node dengan algortima ketiga encoding tersebut diimplementasikan dengan menggunakan Structure Query Language ( $S Q L)$. Dalam penelitian ini, ada dua langkah yang dilakukan. Pertama, transformasi dokumen XML ke dalam sebuah sistem basis data. Sebelum melakukan proses perbandingan, tiga buah sistem basis data dibentuk secara terpisah. Masing-masing basis data tersebut mempunyai delapan tabel yang berisikan kedelapan dataset dari dokumen original XML dan masing-masing tabel mempunyai satu atribut primary key yang berisikan label node dari ketiga metode encoding itu.

Kedua, implementasi proses penambahan node. Untuk melihat perbedaan proses penambahan node baru, satu perintah SQL diimplementasikan untuk menambahkan node baru dan memodifikasikan label sibling node yang diakibatkan karena penambahan node baru untuk masing-masting encoding. Kemudian rata-rata total node yang harus dilabelkan kembali dibandingkan dan ditampilkan melalui grafik. Eksperimen ini dicoba pada dua jenis dataset yang berbeda, yaitu dataset yang dalam (deep dataset) dan yang dangkal (wide dataset).

Penelitian ini menggunakan deep dataset Treebank yang berisikan lebih dari 2 juta node, 36 tingkat maksimum kedalaman tree, dan lebih dari 16 ribu rata-rata fanoutnya. Sedangkan untuk wide dataset, penelitian ini menggunakan dataset dblp-5.

\section{Pengujian dan Pembahasan \\ 4.1. Dewey Encoding}

Dewey encoding yang diusulkan melalui jurnal (Tatarinov, dkk., 2002) merupakan metode pelabelan XML tree dengan menggunakan kode katalog buku. Dalam metode ini, setiap node dilabelkan dengan menggunakan kombinasi antara label parent node-nya dengan sebuah bilangan positif integer. Jika $u$ merupakan anak ke- $x$ dari node $s$ pada XML tree, maka label untuk node $u$, label $(u)$ adalah penggabungan label dari node $s$ dan $\mathrm{x}$ yang dipisahkan oleh sebuah karakter '.', atau dipresentasikan dengan label $(u)=$ label $(s)$.x. Sebagai contoh, jika label node $u$ adalah 1.5.3, maka label untuk child node yang ke-5 dari node $u$ adalah 1.5.3.5.

Metode ini sangat efektif untuk menentukan parent node atau sibling dari sebuah node. Jika label node $u$ adalah 1.5.3.5, maka parent node dari node $u$ adalah 1.5.3 yaitu dengan menghapus sebuah integer terakhir dari label node $u$. Sedangkan semua label node yang memiliki label parent yang sama dengan parent $(u)$ merupakan sibling dari node $u$. Sebagai contoh, label node 1.5.3.1, 1.5.3.6, dan 1.5.3.2 adalah sibling dari node $u$ (berlabel 1.5.3.5). Gambar 4 menampilkan dokumen XML (Kode 1) dipresentasikan menggunakan metode Dewey.

Metode Dewey sangat lemah dalam melakukan proses penambahan node baru (Tatarinov, dkk., 2002). Proses ini melibatkan pelabelan kembali terhadap sibling node dari node baru tersebut. Misalnya sebuah node baru dimasukkan menjadi child node ke-2 dari node yang berlabel 1.2 (book) dan dengan label 1.2.2 (baru). Kemudian Dewey akan melakukan proses label ulang terhadap label node 1.2.2 (title) menjadi label node 1.2.3, begitu juga label node 1.2.3 (chapter) menjadi label node 1.2.4. Hal ini sangat tidak efesien dilakukan ketika sebuah node baru ditambahkan ke dalam tree dan menjadi child node ke-1 dari root. Akibatnya semua node kecuali root harus dilakukan proses pelabelan ulang. 


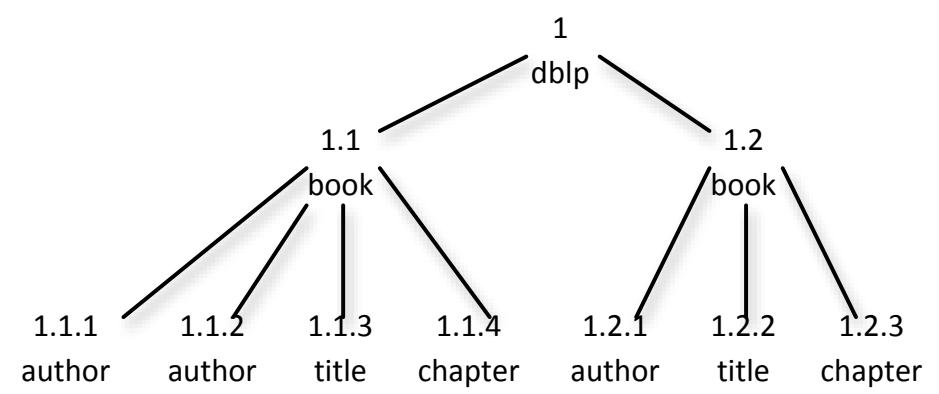

Gambar 4. Konversi Dokumen XML Menjadi XML Tree

\subsection{Interval Encoding}

Interval encoding merupakan metode encoding untuk melabelkan node dengan menggunakan nilai interval (range) dengan teknik penelusuran pre-order traversal (Augsten, 2009). Setiap node mempunyai nilai interval yang terdiri dari dua nilai, left dan right. Karena penelusuran diawali melalui root, maka nilai left untuk root adalah 1 . Kemudian children sebelah kiri dari root ditelusuri dan diberikan nilai leftnya dengan meng-increment-kan nilai left sebelumnya. Begitu juga ketika sebuah node telah selesai ditelusuri, maka nilai right dari node tersebut diinisialisasikan. Gambar 5 menunjukkan XML tree dengan menggunakan label Interval encoding.

Metode ini secara mudah dapat menentukan children/descendant dan parent/ancestor dari sebuah node. Jika node $u$ mempunyai nilai interval yang berada diantara nilai left dan right dari node $s$, maka node $u$ adalah children atau descendant dari node s. Sebagai contoh label node $s_{1}$ dengan nilai interval $\langle 2,11\rangle$ dan node $s_{2}$ dengan nilai interval $\langle 12,19\rangle$ merupakan children dari node $s_{3}$ bernilai interval $\langle 1,20\rangle$. Begitu juga sebaliknya, jika nilai interval node $s$ berada di dalam nilai interval node $u$ dan nilai right dari node $s$ lebih kecil dari nilai right pada node $u$, maka node $u$ merupakan parent atau bisa jadi ancestor dari node $s$. Sebagai contoh, karena nilai interval node $s_{1}\langle 2,11\rangle$ berada di dalam nilai interval node $s_{2}\langle 1,20\rangle$, dan nilai interval right dari node $s_{1}$ lebih kecil dari nilai interval right dari node $s_{2}$, maka $s_{2}$ adalah parent atau ancestor dari node $s_{1}$.

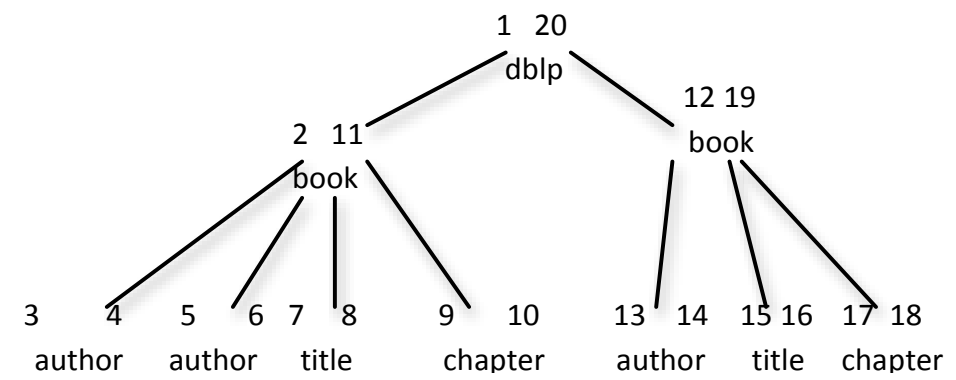

Gambar 5. XML Tree Dengan Label Interval Encoding

Sama halnya seperti dewey, interval encoding juga masih tidak mendukung proses penambahan node baru secara efisien. Karena jarak nilai interval dari leaf node adalah 1, maka proses pelabelan ulang terhadap sibling node tidak dapat dihindari. Kasus proses pelabelan node kembali yang terjadi paling lama adalah ketika sebuah node baru ditambahkan ke dalam tree dan menjadi child node ke-1 dari root. Pada kasus ini, interval encoding harus mendefinisikan kembali nilai interval dari semua node di dalam tree, termasuk juga root dari tree itu sendiri.

\subsection{ORDPATH Encoding}

ORDPATH encoding yang dipaparkan pada tulisan (O'Neil, dkk., 2004) merupakan metode encoding berbasiskan Dewey yang menggunakan bilangan ganjil (lihat Gambar 6). Namun, metode ini juga menggunakan bilangan genap sebagai tanda sisipan (caret) untuk menambahkan node baru ke dalam tree. Tanda sisipan dilokasikan diantara dua buah bilangan 
ganjil. Sebagai contoh pada Gambar 6 ORDPATH memberikan label kepada node baru yang berada di antara "author" (1.1.3) dan "title" (1.1.5). Ketika node baru ditambahkan diantara kedua node tersebut, maka ORDPATH membentuk sebuah caret, bilangan genap antara 3 dan 5, yaitu 2 serta menggabungkan label parent mereka dengan caret tersebut dan bilangan ganjil yang lainnya (misalnya 1). Sehingga label untuk node baru tersebut menjadi 1.1.2.1 tanpa harus memberikan label ulang kepada node "author"(1.1.3) dan "title"(1.1.5). Gambar 7 menunjukkan proses penambahan node baru diantara dua buah node yang dilabelkan dengan menggunakan metode ORDPATH.

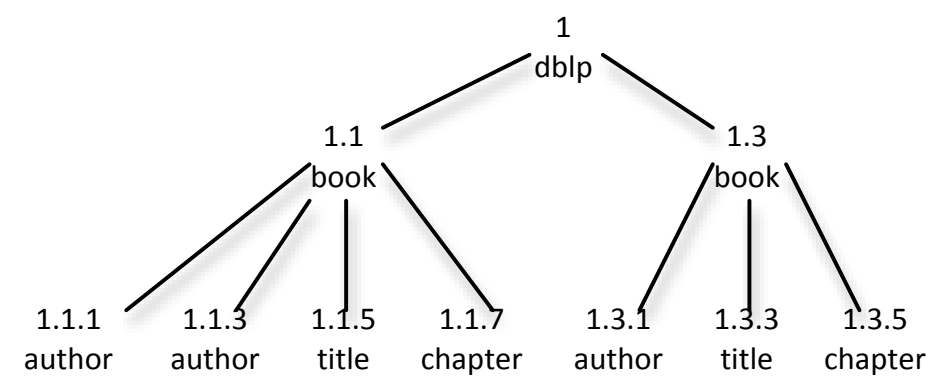

Gambar 6. XML Tree Dengan Label Dewey Encoding

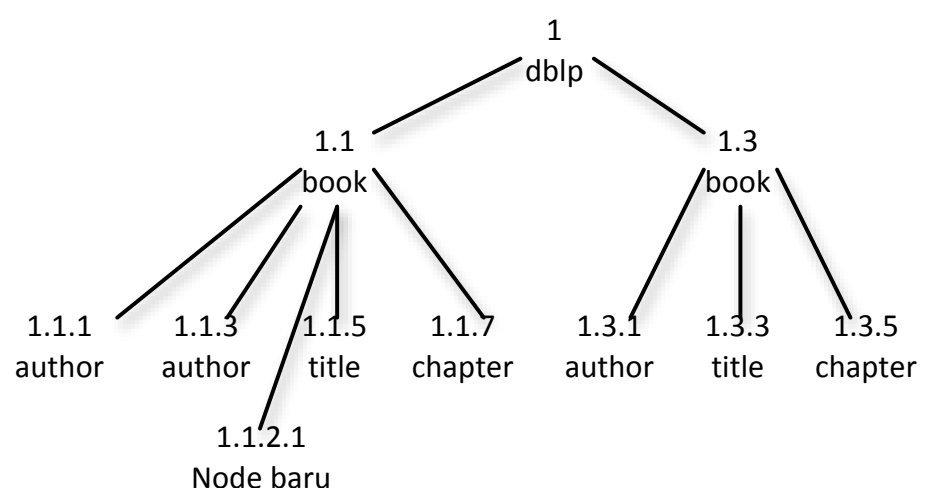

\section{Gambar 7. Penambahan Node Baru Pada Posisi Diantara Dua Buah Node Menggunakan ORDPATH Encoding}

Untuk menambahkan node baru sebagai child pertama dari sebuah node, ORDPATH memberikan label kepada node tersebut dengan menggabungkan label parent dari node baru dengan bilangan ganjil negatif. Sebagai contoh, jika node baru ditambahkan pada posisi sebelum node "book"(1.1), maka label untuk node baru adalah 1.-1 tanpa harus memodifikasikan label untuk node siblingnya. Gambar 8 memperlihatkan sebuah node baru ditambahkan pada posisi sebagai child pertama dari root.

Sedangkan untuk menambahkan node baru sebagai child terakhir dari sebuah node, ORDPATH mendefinisikan label node tersebut dengan menambahkan bilangan ganjil dari node terakhir dengan bilangan 2. Sebagai contoh, jika node baru ditambahkan pada posisi sesudah node "book"(1.3), maka label untuk node baru adalah 1. $(3+2)=1.5$ tanpa harus memodifikasikan label node yang lain. Gambar 9 memperlihatkan sebuah node baru ditambahkan pada posisi sebagai child terakhir dari root. 


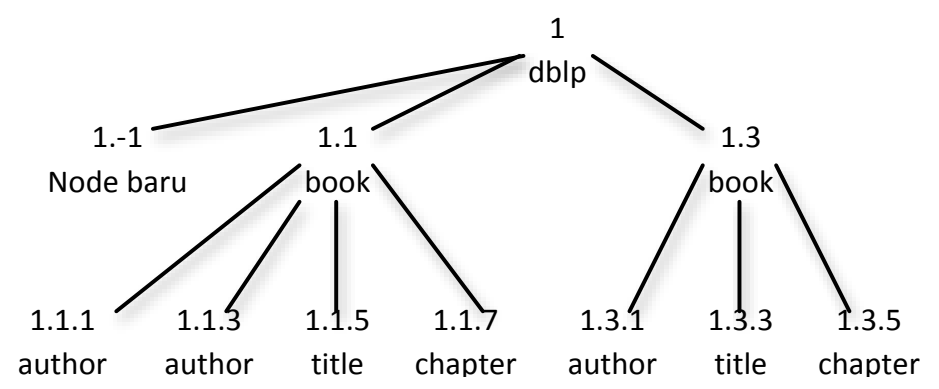

Gambar 8. Penambahan Node Baru Pada Posisi Child Pertama Dari Root Node Menggunakan ORDPATH encoding

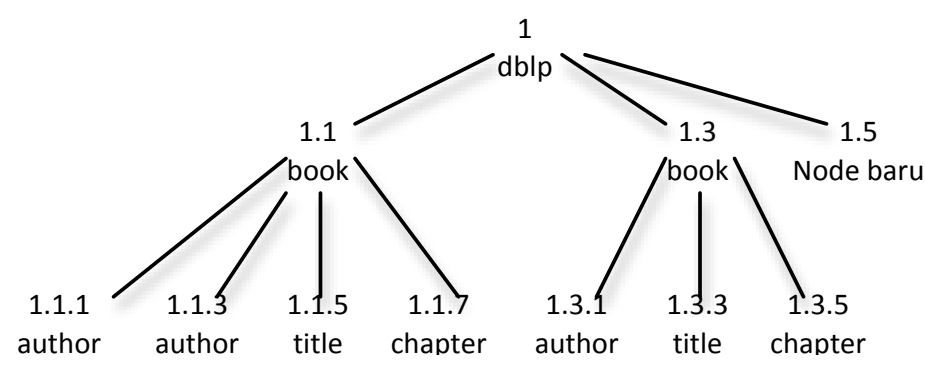

Gambar 9. Penambahan Node Baru Pada Posisi Child Terakhir Dari Root Node Menggunakan ORDPATH Encoding

\subsection{Analisis Proses Penambahan Node}

Dalam bagian ini, proses penambahan node baru dengan menggunakan ketiga metode tersebut ditampilkan dan membandingkan dalam bentuk grafik garis. Untuk eksperimen ini, penambahan node dilakukan dengan menambahkan beberapa node pada posisi acak di dalam dua jenis tree yang berbeda (deep dan wide trees), dan diperlihatkan perbandingan melalui grafik. Gambar 10 menampilkan jumlah node yang harus dilabelkan kembali oleh ketiga encoding setelah proses penambahan beberapa node baru dilakukan pada posisi acak dengan menggunakan wide dataset.

Pada Gambar 10 sangat jelas ditampilkan bahwa ORDPATH encoding mampu mengeliminasikan proses pelabelan ulang saat node ditambahkan ke dalam XML tree. Sedangkan Dewey dan interval encoding cenderung memodifikasi label node dalam jumlah yang sangat besar ketika proses penambahan node dilakukan berulang kali.

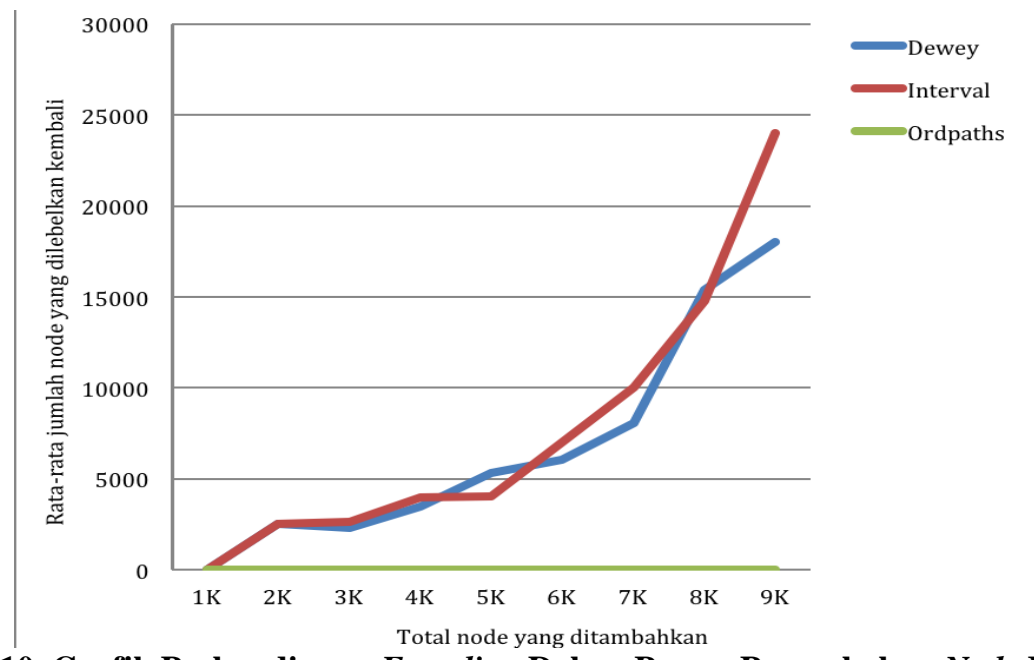

Gambar 10. Grafik Perbandingan Encoding Dalam Proses Penambahan Node Pada Wide Dataset 
Sedangkan pada Gambar 11, ORDPATH encoding masih menunjukkan kehandalannya dalam menambahkan node ke dalam deep tree. Penambahan node dengan metode ini tidak mempengaruhi bentuk, besar, dan kedalaman dari sebuah tree. Namun Dewey sedikit ada peningkatan pada dataset ini dan lebih baik dibandingkan dengan deep dataset. Hal ini disebabkan karena kedalaman tree dan jumlah children dari suatu node mempengaruhi proses relabeling. Dewey akan cepat melakukan proses penambahan node jika jumlah sibling dari node baru tersebut tidak begitu banyak. Beda halnya dengan interval encoding, dimanapun posisi node yang akan ditambahkan, maka seluruh sibling dan descendant dari node tersebut harus dilabelkan kembali.

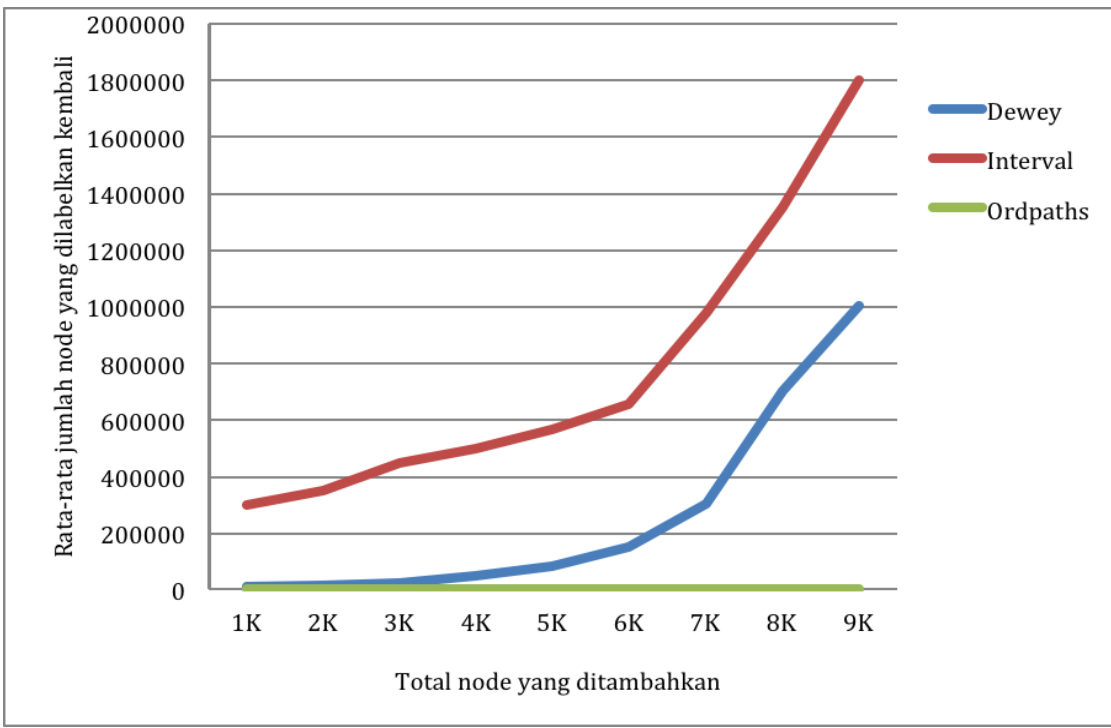

Gambar 11. Grafik Perbandingan Encoding Dalam Proses Penambahan Node Pada Deep Dataset

\section{Kesimpulan}

Dari penelitian ini dapat ditarik kesimpulan: (1) ORDPATH encoding sangat efisien digunakan untuk proses penambahan node pada semua bentuk XML tree. (2) Dewey encoding cenderung baik digunakan jika XML tree berbentuk datar (wide) dengan jumlah node yang tidak begitu besar. (3) Interval encoding sangat tergantung dari jumlah node yang ada di dalam XML tree dan tidak terpengaruh dari kedalaman dan bentuk tree itu sendiri. (4) Penggunaan caret pada ORDPATH encoding sangat efektif diterapkan untuk mengeliminasi proses relabeling node dan tidak ada pengaruh terhadap urutan node di dalam XML tree.

\section{Referensi}

Augsten, N. 2009. Ordered Labeled Trees in a Relational Database, Approximation: Theory and Algorithm Course. Bozen-Bolzano: Free University of Bozen-Bolzano.

Dagys, E. 2008. Storing XML using Interval Encoding with Sparse Numbering. Thesis tidak diterbitkan. Bolzano-Italia: Free University of Bozen-Bolzano.

Deutsch, A., Fernandez, M. \& Suciu, D. 1999. Storing Semistructured Data with STORED. Proc. Of SIGMOD Conference 1999.

Ferraz, C., A., Braganholo, V. \& Mattoso, M. 2010. ARAXA: Storing and Managing Active XML Documents. Web Semantics: Science, Services, and Agents on the World Wide Web 8, hal. 209-224.

Florescu, D. \& Kossmann, D. 1999. Storing and Querying XML Data using an RDBMS. IEEE Data Engineering Buletin 22(3).

Gros, J., \& Yellen, J. 2010. Graph Theory and its Appplication. London: Chapman \& Hall.

Lu, J., Wang Ling, T., Chan, C. \& Chan, T. 2005. From Region Encoding to Extended Dewey: 
On Efficient Processing of XML Twig Pattern Matching. VLDB 2005, pp. 193-204.

O’Neil, P., O’Neil, E., Pal, S., Cseri, I., Shaller, G. \& Westbury, N. 2004. ORDPATH: InsertFriendly XML Node Labels. SIGMOD 2004, pp. 903-908.

Shanmugasundaran, J. 2001. A General Technique for Querying XML Documents using a Relational Database System. SIGMOD Record, September 2001.

Shimura, T., Yoshikawa, M. \& Uemura S. 1999. Storage and Retrieval of XML Documents using Object-Relational Database. Proc. Of DEXA Conference.

Soltan, S., Zarnani, A., AliMohammadzadeh, R. \& Rahgozar, M. 2006. IFDewey: A New InsertFriendly Labeling Schema for XML Data. World Academic of Science, Engineering and Technology, 13, 2006, hal. 116-118.

Tatarinov, I., Viglas, S.D., Beyer, K., Shanmugasundaran, J., Shekita, E. \& Zang C. 2002. Storing and Querying Ordered XML Using a Relational Database System. ACM SIGMOD 2002, June 4-6, Madison, Wisconsin, USA.

Zamanhuri, I. 2014. FDewey Encoding: An approach Based on Dewey for Storing an XML Document into Database. The $2^{\text {nd }}$ International Conference on Natural and Enviromental Science (ICONES) 2014, hal. 207-212. 